\title{
The impact of the International Accounting Standards/ International Financial Reporting Standards (IAS/IFRS) in determining the goodwill of companies in the European Union (EU)
}

\author{
Veronica Grosu ${ }^{1 *}$, Elena Hlaciuc ${ }^{1}$, Dorel Mates ${ }^{2}$ and Marian Socoliuc ${ }^{1}$ \\ ${ }^{1}$ Accounting, Finance and Economics Informatics Department, Faculty of Economics and Public Administration, Stefan \\ cel Mare" University, Suceava, Romania. \\ ${ }^{2}$ Accounting and Audit Department, Faculty of Economics, West University Timisoara, Pestalozzi Street, Timisoara,
} Romania.

Accepted 14 September, 2012

\begin{abstract}
The aim of this paper is to delineate and analyse the notion of goodwill both from the standpoint of the accounting theory and of the economic practice (referring to the valuation and presentation of this asset in the balance sheet) and, to a smaller extent, from a legal perspective. As an economic value, goodwill plays a significant role when determining the value of a company and thus goodwill has become a highly debated topic in the past few years, one that the economic community has tried to delineate in terms of contents and structure, separately from other intangible assets. There are companies on the market that have the same factors of production but are evaluated and considered at different values, because of the very influence of these intangible values. The present paper focuses on this specific context and identifies the changes affecting goodwill as a consequence of the various accounting treatments and particularly the effects of the mandatory observance of the International Financial Reporting Standards IAS/IFRS by all companies quoted on the EU market. Additionally, we will focus on the extent to which the outcome of such valuations can have positive or negative effects on other categories of assets and liabilities and/or on the net worth of the company, on the recorded performance or on its image and notoriety.
\end{abstract}

Key words: Goodwill, assets and resources, accounting methods, International Accounting Standards/ International Financial Reporting Standards (IAS/IFRS).

\section{INTRODUCTION}

\section{CLASSIFICATIONS, TERMS AND DEFINITIONS ACCEPTED BY THE ECONOMIC THEORY}

The main objective of this paper is to explain the definition and the importance of goodwill from an accounting standpoint, that is, in terms of the valuation of this capital element that has become increasingly important for business entities, regardless of their activities. Thus, the first part of the paper explains the concept of goodwill in

\footnotetext{
${ }^{*}$ Corresponding author. E-mail: doruveronica@yahoo.it.
}

economic theory and the way it is interpreted by the financial reporting international standards and by the accounting literature.

The second part of the paper presents a simulation of goodwill valuation in a company that is quoted on the EU market and prepares financial statements in compliance with he IAS/IFRS international standards, alongside a short term (2 years) forecast of the value of this element, given the fact that it has been established depending on the related cash flow generating units (CGU).

The following part focuses on the definitions of goodwill that have been issued by various authors throughout the ages, as well as its position in the classification of 
intangible assets.

As a consequence of the increasing importance of intangible assets within the firm, there is a growing need to capitalize these resources, both through an internal vision, in order to better understand their value, and through an external one, given the negotiations surrounding their release or licensing (Mironiuc, 2009).

The typology of intangible assets has had a significant impact on the temporary life expectancy, that is, shorter for the human capital and for unprotected technologies, and longer for marketing and patent protected technologies (Ernest and Yang, 2007).

In the opinion of Luca (2010), an intangible asset is defined as an asset in the capital of a company, expected to bring economic benefits, without material substance and which can be identified by that company.

One of the generally accepted classifications of economic theory (Renoldi, 1992) is based on the identification criterion, that is, on the separation of the invisible resources of the company into two main categories, as follows: intangible assets, that have autonomous relevance and are thus identifiable (even if not necessarily transferable), and intangible assets that cannot be identified and are included in the value of goodwill and sometimes in the going concern value. As far as identifiable intangible assets are concerned, they are also divided into: contractual and exclusive usage rights over the entity's own goods; intellectual property; relationships of the entity and the goods and services portfolio.

As for unidentifiable intangible assets, the typical defined as such is goodwill, that is, the exclusive result of the correlated action of unidentifiable intangible assets.

The issues related to the assessment and accounting treatment of goodwill has been the main focus of several authors. Goodwill is defined as an asset among other complementary elements of intangible assets, that has is highly significant for the value of the company (Besta, 1922). It is very important to underline the fact that the accounting literature separates fixed intangible assets from intangible resources. There are other authors (Onida, 1974; Zappa, 1950) who believe these assets are among the most significant elements of the company's total assets.

The economic theory does not identify a unanimously accepted definition of goodwill (Bianchi, 1996; Boisiso, 1964; Visconti, 2009); the concept of goodwill is closely related to the characteristics of the company, defined by Zanda (1974) as a highly complex open system, endowed with specific regulations and able to influence the environment it operates in. The concept of goodwill has also been a highly debated topic in marketing theories that no longer focus on the relation between the value of output/sales and profit. Therefore, goodwill (Fabris and Minestrone, 2004) is defined as that strategy that must focus on creating a consumer friendly psychological behaviour.

The various definitions attributed to goodwill abound in the economic literature, both quantitatively and qualitatively. Among the most widely accepted qualitative theories, we can mention:

a) The future benefits or excess profits approach; b) The theory of added-value generated by the organisation.

The first theory defines goodwill as the company's ability to generate future economic benefits. If this is not the case, goodwill will be recorded as a negative value (Mateş and David, 2010).

The second theory is based on a flexible definition of goodwill, as it results from the difference between the market value of the firm and the total current values of the assets that make up the total value of the company's assets.

From a quantitative perspective, there are numerous difficulties in determining the actual value of goodwill and an autonomous (direct) valuation. The direct valuation of goodwill, as an independent asset, may be conducted by identifying and defining each element that can generate goodwill or by updating the future economic benefits (Taliento, 2001). In the former case, the valuation of goodwill may be achieved by calculating the total values of the elements it includes; in the latter case, goodwill is defined as the company's ability to generate more benefits than usually, the so called excess profits approach (De Minico and Amodeo, 1942). One should not overlook the case when investors "distinguish among identifiable components of goodwill for valuation purposes, in the year of acquisition" (Henning et al., 2005).

The most recent definitions of intangible assets (that also include goodwill) describe them as those resources that are based on the information they contain (Itami, 1987), or as those immaterial assets that are used for generating future economic benefits, without having any material or financial support (Lev, 2001).

The most frequently used goodwill valuation methods in the accounting practice are those that calculate goodwill as the difference between the purchase price of the company and the fair market value of the company's asset (Chirichiagno and Segre, 2011). A second method does not take into account the net fair value of identifiable assets but only the adjusted asset. The latter is a value that results from the total value of assets and liabilities that make up the equity capital. Therefore, the first method represents a certain value of a company's economic resources, while the latter stands from the value of the working capital - the so-called residuum approach.

There is also another approach in defining goodwill, consisting in the difference between the economic value of capital and the value of the adjusted asset; actually, the economic value of the capital identified as the maximum value of the entire firm, based on the current 
revenues or on future earnings, may differ significantly from the negotiated price. This is mainly due to the influence of the biased negotiation circumstances, such as: information asymmetry, position of the parties involved, prestige or power, the need to sell or to buy (Guatri and Bini, 2005).

Under such circumstances, the adjusted asset should also include the existing intangible assets, even if they are not calculated. Nevertheless, these assets should meet certain criteria, as follows: they must be identifiable, separable and be assessed accurately. The value can be analysed from at least three perspectives (Zanda and Onesti, 2005) namely:

a) From an ontological standpoint - in this case the question is whether these values exist and what they are, what is their nature, whether they can lead to absolute or just relative values, whether they can be classified or systematized;

b) From a epistemological standpoint - consists in finding a method to identify, know and possibly to assess values; this level is, naturally, in close relation to the previous one;

c) From an ethic and deontological standpoint - the identification of these values leads to a behavioural change theory.

According to the aforementioned presented approaches, the ontological and qualitative characteristics of goodwill prevail before the epistemological and qualitative solutions and difficulties that are closely related to the accounting treatment of goodwill.

Several authors that have analysed the concept of goodwill emphasized the correlation with the necessary costs to be incurred by the company (Yang, 1927), while the evolution of the accounting methods has been thoroughly analysed and studied in France, Germany, Great Britain and the U.S.A. (Yuan et al., 2007).

Therefore, we can conclude that the concept of goodwill is a hot topic that has been widely debated by numerous international authors who have developed a variety of definitions that are more or less accepted and sometimes even severely criticised.

\section{DIFFICULTIES IN THE ACCOUNTING TREATMENT FOR GOODWILL AND THE SUGGESTIONS MADE BY THE INTERNATIONAL FINANCIAL REPORTING STANDARDS IAS/IFRS}

This part of the paper focuses on the essential aspects related to the accounting of goodwill in compliance with the IAS/IFRS standards, including the initial recognition and subsequent accounting and, last but not least, the analysis of the impairment test (included in the range of the IAS 36 standard). In terms of the initial recognition of goodwill, the IAS/IFRS standards allow the accounting of the goodwill acquired in a business combination, whose definition is detailed in the IFRS 3 standard - Business Combination.

The IFRS 3 principles address not just the separate recording in the balance sheet of the so-called acquiring entity of any transactions (mergers, acquisitions and other similar operations), but they should also be applied in the preparation of the consolidated statement, in all cases where the consolidation is based on a relationship of the participant interest type or any other form of control ${ }^{1}$.

The IFRS 3 standard usually regulates the accounting of business combinations through the so-called purchase method (Feleaga and Feleaga, 2006) which, in turn, is divided into the following stages:

a) Determining the acquirer ${ }^{2}$;

b) Determining the costs incurred by the acquirer in order to finalise the consolidation process ${ }^{3}$; the acquisition-date allocation of the cost of the business combination, of the acquired assets and liabilities or contingent liabilities, measured independently from the accounting value they carried in the financial statement of the acquiree ${ }^{4}$.

When applying the purchase method, goodwill is measured as the difference between the cost of the consolidation operation developed by the acquirer and the non-controlling interest of the seller, at the fair value of the assets and liabilities, contingent liabilities identified by the acquired entity and recorded separately in the balance sheet. The method established by IFRS 3 (2004) is best described by the formula:

$$
\begin{aligned}
& \mathrm{G}=\mathrm{C}-\mathrm{q} \times \mathrm{k}^{\prime}, \quad \text { and } \\
& \mathrm{k}^{\prime}=\mathrm{A}_{\mathrm{FV}}-\left(\mathrm{P}_{\mathrm{FV}}+\mathrm{P}_{\mathrm{PFV}}\right)
\end{aligned}
$$

Where, $\mathrm{G}=$ value of the acquired goodwill that must be recorded in the financial assets; $C=$ cost of the consolidation operation, incurred by the acquirer; $q=$ the non-controlling interest of the acquiree (the seller), with $0 \leq \mathrm{q} \leq 1, \mathrm{k}^{\prime}=$ identifiable assets during the acquisition process; $\mathrm{A}_{\mathrm{FV}}, \mathrm{P}_{\mathrm{FV}}, \mathrm{P}_{\mathrm{PFV}}=$ fair value of the assets, liabilities and contingent liabilities identified by the acquiree and recognised separately.

\footnotetext{
${ }^{1}$ In the process of consolidation can be a link between entity mother and branch in which the buyer is the one that controls, and the entity purchased is controlled by the buyer. In these conditions, the buyer applies IFRS 3 in drafting the consolidated balance. This illustrates in fact its own interests with respect to the acquisition operation, such as participation interests in a controlled entity, in any balance published (IFRS 3 - Bussiness Combination, paragraph no 6,2004$)$.

${ }^{2}$ IFRS 3-Business Combination, paragraph no. 17-23.

${ }^{3}$ IFRS 3-Business Combination, paragraph no. 24-35.

${ }^{4}$ IFRS 3-Business Combination, paragraph no. 36-65.
} 
Upon the adoption of the IFRS 3, the IASB also developed a unique guide in favour of the purchase method; initially, the IAS 22 standard allowed only the recording of the consolidation operations and methods at book value - pooling of interest method; the reason for developing the IFRS 3 standard was the fact that it allows and also guarantees a better comparison between balance sheets.

Therefore, the purchase method states that the acquirer must recognise and measure the assets and liabilities of the acquiree at the acquisition-date fair value. It is well-known that, after a business combination, an asset or a liability is first measured in the balance sheet at its fair value or, more accurately, at its acquisition-date fair value, but this does not entail a deviation from the principle of the historical cost; the historical cost and the fair value of an asset or liability always coincide at the acquisition date (Pettinicchio, 2004).

Hence, according to the IAS/IFRS standards, the accounting treatments only cover the derived goodwill or the one generated by the acquisition of an enterprise, subsidiary or sector of an entity, without providing any measures for recognising the internal goodwill generated by production synergies or current activities. Actually, goodwill is determined quite simply, as resulting from the utility costs incurred in time and which were included in the price paid when acquiring a business entity or just a part of it, but included in the assets of the acquired entity.

Reference is often made in the accounting practice to the importance of properly defining goodwill, as it must consist in the difference between the price paid for acquiring an entity and the value of the assets and liabilities and non-controlling interests (Istrate, 2010; De Muri, 2005) (Figure 1).

According to the IFRS 3 and IAS 36 standard, goodwill is the payment made by the acquirer with the aim of acquiring future economic benefits derived from assets that cannot be separately recognised and measured. Goodwill is actually the value of the expected synergies generated by the reputation of the entity, its experience, professionalism, consolidated procedures, premises and other factors.

The value of the acquired goodwill consists in the difference between the price paid and the fair value of the purchased assets and liabilities (including intangibles and assumes liabilities that could not be recognised before the acquisition date but whose characteristics prevent them from being recorded in the financial statement).

The most popular formula used by the accounting professionals when determining goodwill is the following:

$$
\text { Goodwill }=(\mathrm{V}-\mathrm{i} \times \text { APR }) \mathrm{a}_{\mathrm{n}-\mathrm{i}^{\prime}}
$$

Where: $\mathrm{V}=$ annual revenues;

APR = adjusted equity, equal to the difference between assets and liabilities items, expressed in net current value and taking into account the identifiable and measured assets and liabilities items;

$\mathrm{i}=$ rate of return, defined as indicator of the minimum revenue required by real and potential investors in order to invest it into a certain entity performing in a certain sector;

$\mathrm{n}=$ number of years (assumed) when certain excess profits may occur (the so-called useful life of goodwill);

$\mathrm{i}^{\prime}=$ discount rate of the added value.

As far as the goodwill acquired in a business combination is concerned, it mustn't be amortised but undergo an annual valuation, i.e. the so-called impairment test. This particular procedure replaces the systematic amortisation (annual percentage measured in relation to fiscal provisions) with the economic amortisation that basically reflects the actual evolution of the value.

The measurement and the amortisation of goodwill is included in IFRS 3, specifically for business combinations through which two or more enterprises unite to form a single business entity (Figure 2).

The IAS 36 -Impairment of Assets delineates the procedures to be applied in an impairment test. The main differentiating element is the transition from the historical cost to the fair value of assets and liabilities acquired, with the purpose of conveying greater economic relevance to the accounting information and also to reconcile the prudence principle with the objective recording of the transactions (Ernest and Young, 2005).

Thus, the concept of fair value becomes more relevant, as well as the market value, unlike the book value; therefore, the economic practice and theory identify a connection between the operating need and the enterprise valuation technique.

One of the main difficulties encountered by the IAS 36 standard is related to the identification of cash generating units (CGU); thus, when performing an impairment test, the reference term for certain specific business units is used - cash generating units or CGU - not just for the whole company or for the entire group. The use of CGU in performing the impairment test for goodwill is essential: actually, goodwill does not generate cash flows independently from other assets or groups of assets.

This impairment method is specifically designed to surpass the excessive formal rigorousness of the systematic approach but, on the other hand, it also emphasizes the biased treatment of the balance sheet items. This is one of the reasons why there may be an unwanted distribution of the capital or the formation of secret reserves.

From an accounting information standpoint, this approach has certain benefits, depending on the presentation of the so-called accurate image of the company's equity capital. But, given the limitations and hindrances 


\section{Overstatèment}

\section{Control premium}

Value of future

svnergies

\section{Intangible assets not} recognised in the

\section{Added value of tangible and intangible assets}

\section{(and intangible assets}

BV (Book Value)

Figure 1. Goodwill to bargain price ratio. Source: adapted from De Muri (2005).

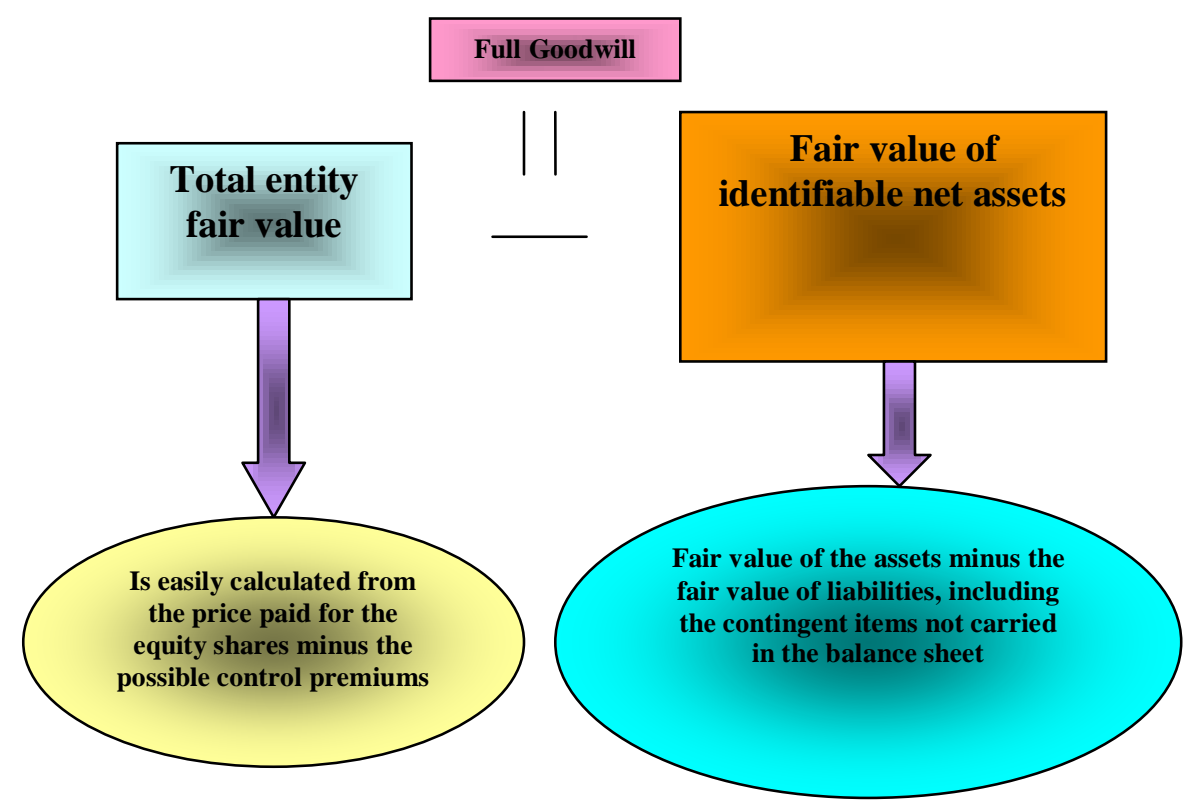

Figure 2. Determining goodwill on a business entity level.

occurring in the valuation of goodwill, this item is not included in the range of the IAS 38 - Intangible assets standard; the importance of goodwill, for all quoted enterprises, actually resides in the value that exceeds the total assets presented in the balance sheet.

However, the IAS 36 standard defines the criteria an entity has to meet in order to make sure that its own assets are recognised in the balance sheet and measured at a higher value than the recoverable amount; basically, one needs to identify the assets that are measured at a higher value than the one they would be assigned when used or sold.

According to the IAS 36 standard, the impairment test should be carried out for each asset recognised in the balance sheet, except for a few cases: when it is not possible to identify the recoverable value of an asset under valuation, the recoverable amount is determined for the CGU to which the corporate asset belongs ${ }^{5}$.

\footnotetext{
${ }^{5}$ IAS 36, paragraph no. 6 .
} 
The valuation formulae included in the IAS 36 standard are:

$$
\mathrm{EV}=\sum_{\mathrm{t}=1}^{5} \frac{\mathrm{UCF}_{\text {pretax }_{\mathrm{t}}}}{\left[\frac{(1+\text { wacc })}{(1-\mathrm{tc})}\right]}+\left\{\frac{\mathrm{UCF}_{\text {pretax }_{5}}\left(1+\mathrm{g}_{\infty}\right)}{\left[\frac{\left(\text { wacc }-\mathrm{g}_{\infty}\right)}{(1-\mathrm{tc})}\right]} \times \frac{1}{\left[\frac{(1+\text { wacc })}{(1-\mathrm{tc})}\right]^{5}}\right\}
$$

Where: UCF $=$ pre-tax unleveraged cash flows (the socalled free cash flow from operation); WACC $=$ weighted average cost of grossed-up capital of the equity determined by the specific financial structure and assets structure; $g=$ the growth rate of the terminal value that must not exceed the growth rate of GDP or the growth rate of the particular economic sector.

$$
\mathrm{W}_{\mathrm{c}}=\sum_{\mathrm{t}=1}^{5} \frac{\text { Fcfe }_{\text {pretax }_{\mathrm{t}}}}{\left[\frac{(1+\text { coe })}{(1-\mathrm{tc})}\right]}+\left\{\frac{\text { Fcfe }_{\text {pretax }_{\mathrm{s}}\left(1+\mathrm{g}_{\infty}\right)}}{\left[\frac{\left(\mathrm{coe}-\mathrm{g}_{\infty}\right)}{(1-\mathrm{tc})}\right]} \times \frac{1}{\left[\frac{(1+\mathrm{coe})}{(1-\mathrm{tc})}\right]^{5}}\right\}
$$

Where: Fcfe pretax = unleveraged pre-tax cash flows (the so-called shareholder equity); $\mathrm{COE}=$ the cost of grossed up capital of the financial leverage, based on the capital assets pricing model; $g=$ the growth rate of the terminal value that must not exceed the growth rate of GDP or the growth rate of the particular economic sector.

CGUs are the smallest groups of assets that generate cash flow and are independent from the cash flow generated by other groups of assets. When identifying this group, the company must consider various factors and specifically focus on the way in which the management is monitoring the operational level of the different business units and the way in which they will make the decisions related to the continuation or lease of the assets or of the economic activities.

Therefore, it is very important to maintain a very reliable internal monitoring and identify the input and output flows related to each CGU, including the budgets and forecasts for each unit. CGUs cannot be created artificially by adding up all kinds of assets, but they must be clearly designed as business units that the internal management of the entity can monitor, together with the cash flows the unit generates.

In practice, the delineation of cash generating units may sometimes be quite difficult; given the independence and autonomy of the cash flows generated by a CGU, all the in primis factors must be considered, such as the entity that organizes and develops the control of the operations for production lines, business sector or geographical area, as well as the way in which the entity motivates its strategic decisions (Ernest and Young, 2005). The carrying amount of a CGU can be described as follows:

a) It only includes the book value of those assets that can be assigned directly or reasonably allocated to the CGU and which will generate the future cash flows estimated for establishing the value in use of the CGU;

b) It does not include the carrying amount of any identifiable liabilities, except for the case when the recoverable amount of the CGU cannot be determined without taking into account this debt.

An impairment loss must be identified when the carrying amount of the CGU is higher than its recoverable amount. The loss must be allocated in order to reduce the carrying amount of the assets of the CGU as follows: firstly, to the goodwill allocated to the CGU (if it exists); and then compare the recoverable amount of the CGU with the carrying amount, recognising an impairment loss where the case may be.

The aforementioned reductions must be recognised as impairment loss for individual assets, as previously discussed. If there is no other practical way of estimating the recoverable amount of each individual asset of the CGU, the standard provides that the impairment loss be randomly allocated among the assets of the unit. The nature of goodwill is defined as follows (Amaduzzi, 2005):

1. The positive difference between the fair value of the acquired assets and their book value;

2. Fair value assets unrecognised in the balance of the acquired entity (intangibles);

3. Fair value of the going concern element;

4. Fair value assigned to future synergies;

5. Overstatement of the price paid (shares);

6. Overstatement due to the contraction stage.

It is very important to mention that the periodical valuation of goodwill also alters information systems and procedures and gives rise to subjectivity in preparing the balance sheet, apart from the identification and valuation of the assets that also covers unrecognised intangible assets and contingencies.

The identification, measurement and assignment of the possible impairment losses according to the IAS 36 standard is a process that all accounting professionals must comply with. For each reporting period, the entity must assess whether there are any factors that may signal possible impairment losses of the assets recognised in the balance sheet. This analysis is actually a preliminary version of the impairment test that signals the presence of these factors; the IAS 36 standard includes a list of the elements that may be considered when any impairment may occur, and these elements are divided into two categories, depending on the origin of the information source ${ }^{6}$.

According to the general rule, if an asset may record impairment loss at the date when the balance sheet is prepared, the entity must carry out a valuation of its

\footnotetext{
${ }^{6}$ IAS 36, paragraph no. 13.
} 
recoverable amount ${ }^{7}$. The recoverable amount at the end of each reporting period is not carried out automatically, but depending on the positive result of the screening test that determines the loss in value.

More specifically, when carrying out an impairment test, one must assess beforehand the possible influence on the recoverable amount. Therefore, the relevance principle that must be observed in assessing the impairment loss indicators will lead to a subsequent discretionary appreciation; moreover, it also enables the entity to skip the most complicated and costly stage of the valuation procedure, that is, the actual valuation of the recoverable amount.

In the case of the goodwill acquired in a business combination, the acquirer will have to carry out the impairment test at least on a yearly basis ${ }^{8}$; the same thing is mentioned in the north-American SFAS accounting standard no. 142-Acoounting for Goodwill and other Intangibles Assets (Charles et al., 2004). The IAS 36 standard also mentions that if an asset suffers an impairment loss, the entity must revaluate the useful life of the asset, the amortisation method, and its residual value, as well as the residual value of those assets that are not suffering any impairment loss ${ }^{9}$.

\section{THE IMPACT OF MEASURING GOODWILL ON THE ENTITY'S OUTPUT AND VALUE}

It is very important to be fully aware of the macroeconomic circumstances of the country or the countries where the goodwill generating entity is operating, apart from the economic sector it operates in. Actually, the economic theory argues that the general circumstances in one country, such as economic or social factors, influence the value of business entities even more so than their specific behaviour which is often severely criticised (Burciu et al., 2010).

Goodwill usually consists of a series of intangible elements that enable the entity to gain extra profit. These factors may be either subjective or objective in nature, namely:

1. Subjective or personal factors - are closely connected to the personality of the entrepreneurs, to the commercial qualities or the ability to manage, etc; and, since these are personal characteristics, they are considered to ne non-transferable factors;

2. Collective or real factors - have an intrinsic nature, as they are related to the organisation of the entity and mainly consist in: efficient and experimented management, technology available, the structure of the management, of the research and development sector and of the

\footnotetext{
${ }^{7}$ IAS 36-Impairment Assets, paragraph no. 9.

${ }^{8}$ IAS 36-Impairment Assets, paragraph no. 10.

${ }^{9}$ IAS 36-Impairment Assets, paragraph no. 17.
}

production sector, efficient selection and training of the personnel, optimal management of the distribution and sale processes, corporate image, wide range of products, thorough knowledge of the market and of the specific economic sector, profitable relationships with the suppliers, quantitative and qualitative structure of the customer portfolio, notoriety of the firm, consumer loyalty, prestige of the entity in its relationships with third parties, etc.

Associated equity, that is, those investments that are not inherent to the typical accounting treatment, is usually measured separately (regardless of the valuation method employed). An output that is not cleared from all other operational values will generate an unreliable valuation result.

The valuation of goodwill is not independent, as it is included in the profits dynamics. The economic and the juridical literature abound in disputes about the nature and characteristics of goodwill. The goodwill of an entity used to be identified through its client list, which was practically the paramount element of that business entity; nowadays, goodwill is a quality of the entity that is under the influence of several factors, starting with the company's client list, premises and managerial skills of the entrepreneurs, etc. The value of the firm is briefly summarised in Figure 3.

The difference between a new company and one that has been producing output for a while consists in the fact that the latter reaches its target by efficiently organising its production factors for its basic economic activity; this is a specific quality of an operating company.

Therefore, the already operating company takes advantage of a series of favourable factors that fuel its capacity to reach the set objectives and to make a profit. This is the reason why, when an operating entity is purchased, the acquirer acknowledges the value of goodwill and thus avoids the risks of failure and the costs of the undertaking.

As an economic value, goodwill is highly important every time a company or one of its subsidiaries must undergo valuation, especially before being transferred or when other ordinary or extraordinary operations require valuation. Goodwill may be either positive or negative; positive goodwill is defined in quantitative terms, as the difference, at a certain date, between the total value of the company and the sum of the current values (assets and liabilities) that make up equity capital. Negative goodwill is identified when the price paid for the acquisition is less than the fair value of its net assets (or the average net assets measured for the previous three years).

From a quantitative standpoint, negative goodwill means the decreased value of the capital of a company that is incurring losses, that is, a value that is less than its net assets. In terms of efficiency, one could say that negative goodwill defines a functional arrangement that is worth less than the separate value of each element it 


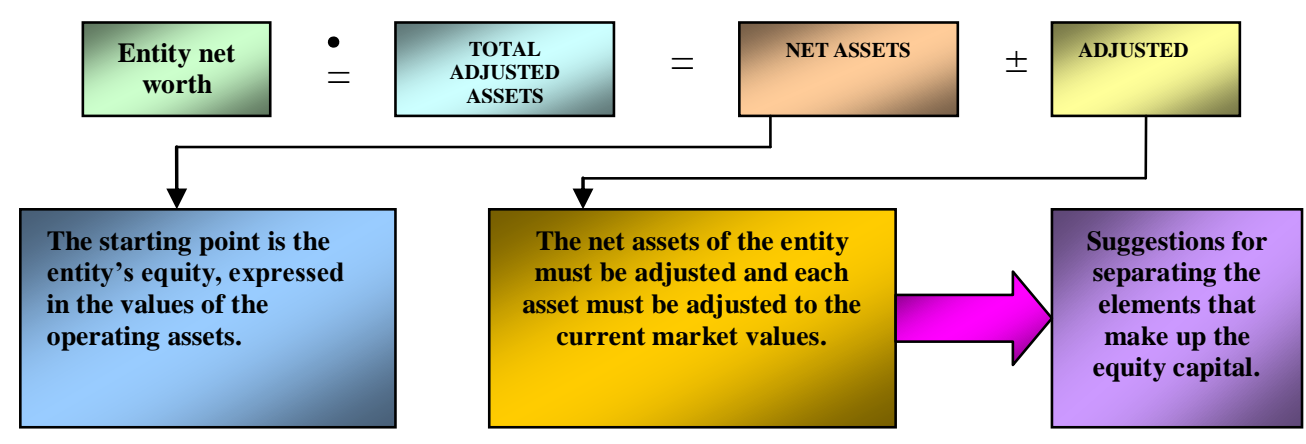

Figure 3. Market value of the firm and relationship with the equity capital.

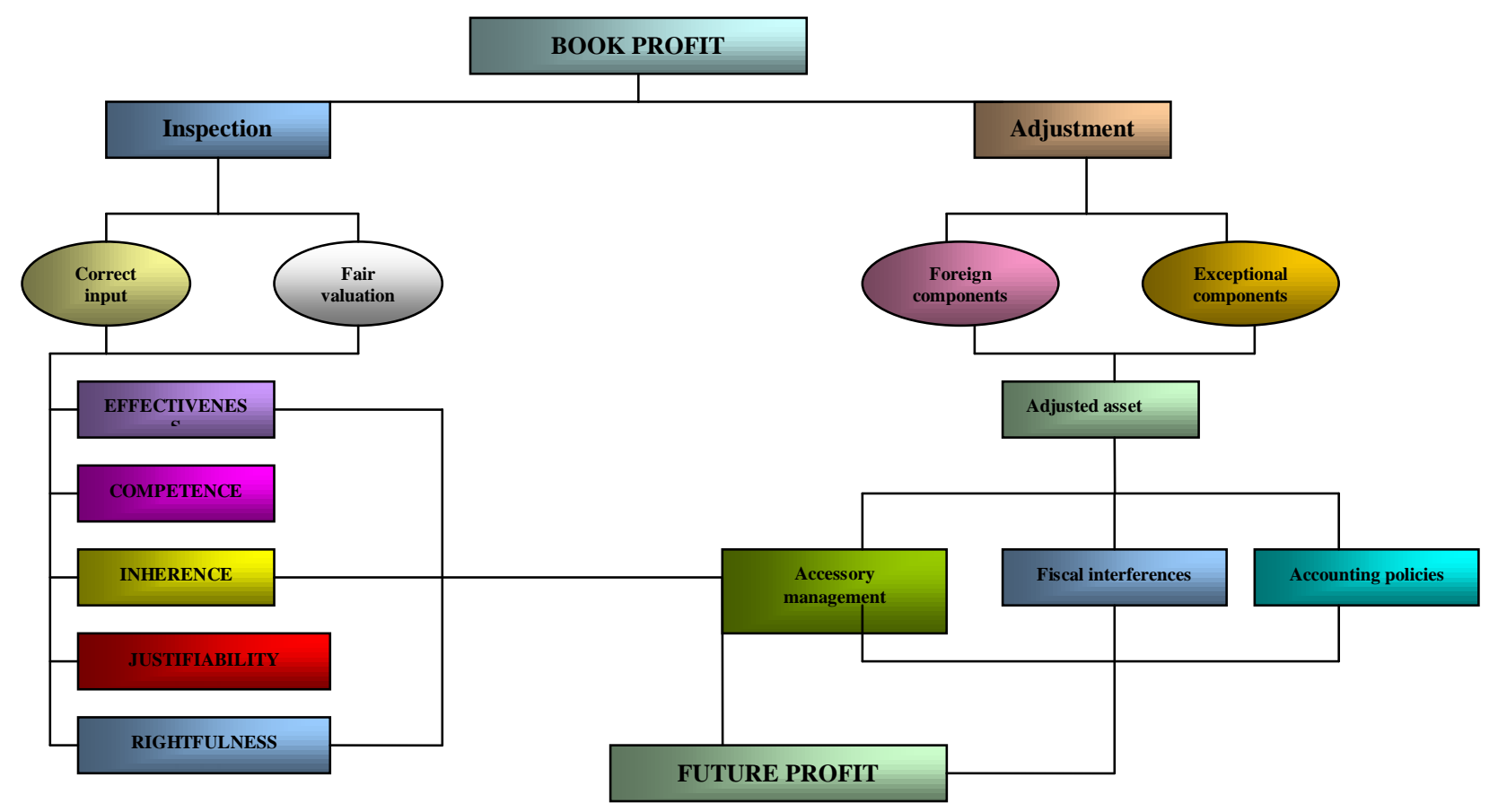

Figure 4. Ratio between the book profit and the future profit of the company.

incorporates. In such cases, the losses have a relevant weighing on the value of equity, since they often lead to a decreased market value of the company, a value which is under the minimum accepted level for an operating entity.

If the crisis faced by that particular entity is not a very serious or long one, or if there is any chance the situation will improve in the short term and without damaging the financial structure, a positive goodwill may be measured. And, since the revenue approach assigns excessive value to goodwill, it should be separated from other intangibles and capitalized at a higher rate, given the high risk it incorporates. If we were to relate the book profit and the future profit, the ratio is pictured in Figure 4.

Profit must first be adjusted, that is, cleared of any extraordinary components (either positive or negative) such as pluses or minuses in value, overstatement of assets or liabilities, revaluations and depreciations, value of financial expenses and taxes. The objective of such an adjustment process is to identify the real and steady profitability of the firm by eliminating the non-recurring, unique and irrelevant elements that may occur. The adjustment in time and of the previous financial reporting should include: the reallocation in time of the non-recurring revenues and expenses; carrying out the expenses and revenues that do not fall under the company's management; correcting the financial reporting policies.

Therefore, it is apparent that the independent value of goodwill in the valuation of the company - consisting in the value of the adjusted net assets and the value of goodwill - generates an added value, apart from the usual profit made, and this value is measured by adjusting these values throughout various accounting periods 


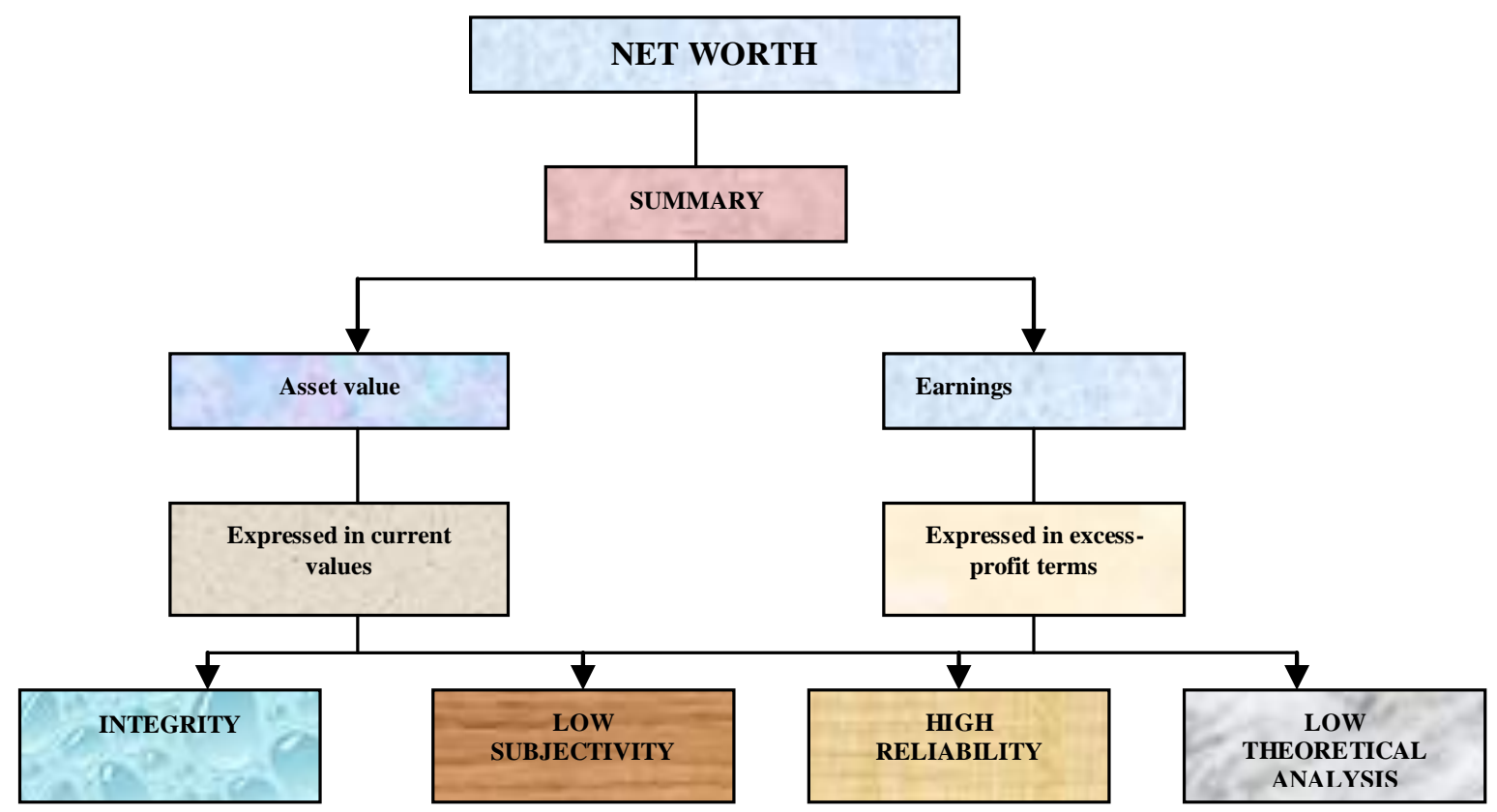

Figure 5. Company's net worth between net assets and retained earnings.

Figure 5.

\section{AN ANALYSIS VALUATION OF GOODWILL AND AN IMPAIRMENT TEST CARRIED OUT AT THE BETA S.A. GROUP}

"Within the contemporary economy we can notice a phenomenon of development and flowering of many groups of societies that have sometimes one fixed purpose or other times, multiple and diverse objectives. The consequence of this phenomenon is that in the modern society, there is no activity sector of activity where there are not present multinational groups with a world or even globalization attempt" (Tiron, 2005).

The importance of valuating intangible assets and particularly goodwill in the process of value creation and sharing, as well as the need to consider these intangibles among other instruments of economic and financial communication has already been confirmed, both on an academic level and in the accounting and economic practice in general.

The following part of the paper will focus on how to assess and measure goodwill on a group level, in this particular case under the generic name of Beta S.A. The available data are provided by the annual financial statements of the group, for the 2009 and 2010 accounting periods. The Beta S.A. group prepares the annual financial statements in compliance with the international accounting standards IAS/IFRS. The fictitious company name was chosen in order not to damage the image, prestige and notoriety of the company on the market, given the forecasts made for the years 2011, 2012 and 2113 on the valuation and the impairment test of the recognised goodwill.

The goodwill was determined in relation to the CGU, the organisational structure and the methods used for controlling the activity; the main reductions or additions to the value of goodwill recorded in the years 2009 and 2010 were mainly due to:

1. Gaining control in other entities and consolidation;

2. The effect of the exchange rate fluctuations for those entities operating outside the European context;

3 . The decrease in the value of goodwill after the carrying out of the impairment test at the subsidiary number 3 ;

4. The reduction in the value of goodwill as a consequence of giving up ownership interest in two of its subsidiaries.

According to the consolidation principles, the value of the equity interest in each of its subsidiaries was excluded from the consolidated statement; at the same date, the goodwill described throughout the paper is included in the category of intangible assets, while the contingent profit derived from an unfavourable acquisition (negative goodwill) is recorded in the profit and loss account. According to the IFRS 3 standard, goodwill is recognised in the consolidated statement at the moment of acquiring control over a business and is described as the surplus between (a) and (b), where:

(a) is equal to the sum between:

i) Paid values (valuated according to IFRS 3, which is generally determined based on the acquisition-date fair 
value);

ii) The sum of all the non-controlling interests in the identifiable assets at the acquisition-date, measured at fair value;

iii) In the case of a step acquisition, the acquisition-date fair value upon acquiring the controlling interests in the acquired entity.

(b) Is the fair value attributed to the assets identified at the acquisition date and the value of the identifiable liabilities, excluded at the acquisition and control date?

Goodwill is defined as an intangible asset yearly or even sooner than the recovery of the value - the so-called impairment test - if any events or changes occur in the circumstances that may indicate impairment losses as delineated in IAS 36; the initial value is not maintained, regardless of the reasons why this depreciation occurred. The valuation is usually carried out at the end of each accounting period and goodwill is allocated at the acquisition-date to each unit or cash flow resulting from the acquisition.

The book value of the CGU (or group of CGU) generates the so called recoverable value that is recorded separately in the profit and loss account, as a decrease in value. The impairment loss is first attributed to the decreased carrying the goodwill amount allocated to the CGU (or group of CGU) and only after that to other assets, in relation to the book value, until the amortisation of the recoverable amount of the assets with limited useful lives. The recoverable amount of a CGU (or a group of CGU) the goodwill is allocated to, is the highest value of the fair value, after subtracting the value in use sale costs associated with that unit.

The value in use of an asset consists in the current value of the cash flows and is calculated by applying a discount rate that reflects the current market assessments of the time value of money and the risks specific to that activity. The future cash flows refer to those forecasted for a definite period of time and in relation to the estimated terminal value. The long term growth rate used to assess the terminal value of a CGU (or group of CGU) is used to a limited extent, so that it will not exceed the average long term growth rate associated with that specific sector or with the market the CGU operates on.

The value in use of an external CGU is estimated in the national currency and then discounted using a discount rate appropriate for that currency. The current value thus obtained is converted into Euros based on the spot exchange rate at the date of the value in use for calculation (for all the subsidiaries of the group, upon concluding the balance sheet). Future cash flows are measured depending on the current circumstances existing in the CGU (or group of CGU), and are viewed as neither benefits deriving from future re-structuring the unit has not yet performed nor future investments into updating or optimising the unit.
In order to measure the loss in value, the carrying amount of a CGU is determined by the criterion used to assess the recoverable amount of the CGU, by excluding the so-called surplus assets, that is, financial assets, prepaid taxes and payable fixed assets, and including the part of goodwill attributed to minority shareholders.

After valuating the loss in value of the CGU (or group of CGU) the goodwill is allocated to, the next step is to check the depreciation in value, by including corporate assets that generate positive output flows and which cannot be allocated to each unit according to a rational and coherent criterion.

In this second stage, the recoverable amount of all the CGU is compared to the carrying amount of all the CGUs (or group of CGU), including those units that have not been allocated any goodwill, as well as the centralised assets.

The formula we have used in order to calculate the recoverable amount is presented as follows:

Recoverable amount $=\sum_{\mathrm{x}=1}^{\mathrm{N}} \frac{\mathrm{UCFFx}}{(1+\mathrm{WACC})^{\mathrm{x}}}+\frac{\mathrm{UFCFn}(1+\mathrm{g})}{(\mathrm{WACC}-\mathrm{g})(1+\mathrm{WACC})}$

Where: $N=$ frame of reference, UFCTx = cash flows generated by the inventory during the $x$ accounting period; UFCTn = sustainable cash flows, beyond the frame of reference; $g=$ growth rate factor of the contingent benefit flows, beyond the frame of reference; WACC $=$ weighted average cost of the grossed-up capital of the financial leverage based on the specific financial structure on the assets

In the case of the Beta S.A. group, the following data has been recorded:

WACC pretax $=10.04 \%$

Discount rate $=1.5 \%$

Frame of reference $(\mathrm{N})$ is of 3 years.

For the same reasons mentioned earlier, the group subsidiaries will be called Subsidiary 1, Subsidiary 2, Subsidiary 8 and parent company.

In order to estimate the recoverable amount, the value in use has been determined by means of the discounted cash flow method by taking into account the cash flows generated by the operations, as established in the strategic plans approved by the company management.

The unleveraged free cash flow (UFCF) generated by each CGU for the frame of reference (2011 to 2013) is reported. An expanded formula would result in:

$$
\frac{\mathrm{UFGF}_{1}}{\left(1+\mathrm{WACC}_{1}\right)}+\frac{\mathrm{UFCF}_{2}}{\left(1+\mathrm{WACC}_{2}\right)}+\frac{\mathrm{UFCF}_{3}}{\left(1+\mathrm{WACC}_{3}\right)}
$$

Where each term stands for the discounted cash flow of 
Table 1. The carrying value of goodwill at the Beta S.A. group during 2009 to 2010 and adjustments.

\begin{tabular}{lccc}
\hline CGU & $\begin{array}{c}\text { Goodwill recorded in 2009 } \\
\text { (million } € \text { ) }\end{array}$ & $\begin{array}{c}\text { Goodwill recorded in 2010 } \\
\text { (million } € \text { ) }\end{array}$ & $\begin{array}{c}\text { Absolute adjustments } \\
\text { (million } € \text { ) }\end{array}$ \\
\hline Subsidiary 1 & 30129.70 & 32.180 .88 & 2051.18 \\
Subsidiary 2 & 15730.20 & 16830.12 & 1099.92 \\
Subsidiary 3 & 7820.10 & 8020.17 & 2000.07 \\
Subsidiary 4 & - & 50.04 & - \\
Subsidiary 5 & 80.16 & - & -80.16 \\
Subsidiary 6 & 6200.03 & 6520.18 & 320.15 \\
Subsidiary 7 & 4208.82 & 4318.05 & 109.23 \\
Subsidiary 8 & - & 42.80 & - \\
Parent company & 104532.84 & 125.882 .61 & 21349.77 \\
\hline
\end{tabular}

Table 2. The value of CGU estimated by the Beta S.A. group for the period 2011 to 2013.

\begin{tabular}{lccc}
\hline Group subsidiaries & CGU value in 2011 & CGU value in 2012 & CGU value in 2013 \\
\hline Subsidiary 1 & 2812.42 & 2862.42 & 2912.42 \\
Subsidiary 2 & 1420.64 & 1460.64 & 1500.64 \\
Subsidiary 3 & 820.31 & 850.31 & 880.31 \\
Subsidiary 4 & 642.68 & 667.68 & 692.68 \\
Subsidiary 5 & 468.25 & 483.25 & 508.25 \\
Subsidiary 6 & 570.09 & 590.09 & 610.09 \\
Subsidiary 7 & 378.12 & 398.12 & 410.12 \\
Subsidiary 8 & 250.35 & 260.35 & 270.35 \\
Parent company & 9242.83 & 9642.83 & 10042.83 \\
\hline
\end{tabular}

the year of reference, and the sum of all three has resulted in the operating value of CGUs that will be presented in Table 3 and Graph 2.

Discount rate $=\frac{1}{(1+d)^{n}}$

Where: $\mathrm{n}=$ year of reference (in this case it will be assigned the values 1, 2 and 3); and $d=1.5 \%$

The discount rate values calculated for 2011, 2012 and 2013 are as follows:

Year 2011: 0.909091

Year 2012: 0.826446

Year 2013: 0.751315

If we apply the discount rate for the future value in use of the CGU estimated to be gained by each subsidiary during 2011 to 2013, the resulted values will be as follows:

The estimation of the terminal value takes into account the sustainable contingent cash flows over the frame of reference (UFCFn) whose value is equal to the unleveraged free cash flows of the last year, that is, UFCF3. Thus, the data obtained from the formula:

$$
\frac{\operatorname{UFCFn}(1+\mathrm{g})}{(\mathrm{WACC}-\mathrm{g})(1+\mathrm{WACC})}
$$

Where: $\mathrm{g}=0.26 \%$ and WACC pretax $=11.60 \%, \mathrm{i}=3$, generates the following data:

The sum of the values obtained in Graph 1, Tables 1 and 2 , that is, the sum of the value in use and the terminal value (of each entity), will reach the following residual (recoverable) value.

The impairment loss test for goodwill has been carried out through the carrying value of the CGU and their residual value; the latter is the highest amount of the fair value less costs to sell and the value in use of the same unit (CGU). Apart from other methods, this complex assessment procedure also entails the use of the discounted cash flow method which requires strict observance of certain conditions in cash flows projections.

It can be easily observed that the residual value is significantly dependent upon the value WACCpretax used in the future cash flow projections model and on the growth rate used for extrapolation Table 4 and 5; Graph 3 and 4.

The positive adjustment of the goodwill as described in the present analysis is mainly due to the acquisition of controlling interests in other entities, to the subsequent 
Table 3. The value in use of the future CGU estimated to be gained by each subsidiary of the group during 2011 to 2013.

\begin{tabular}{lcccc}
\hline CGU & $\mathbf{2 0 1 1}$ & $\mathbf{2 0 1 2}$ & $\mathbf{2 0 1 3}$ & Value in use \\
\hline Subsidiary 1 & 2556.74 & 2365.63 & 2188.14 & 7110.51 \\
Subsidiary 2 & 1291.49 & 1207.14 & 1136.45 & 3635.08 \\
Subsidiary 3 & 745.73 & 702.73 & 661.39 & 2109.85 \\
Subsidiary 4 & 584.25 & 551.80 & 520.42 & 1656.47 \\
Subsidiary 5 & 425.68 & 339.38 & 384.90 & 1149.96 \\
Subsidiary 6 & 518.26 & 487.67 & 458.36 & 1464.29 \\
Subsidiary 7 & 343.74 & 329.02 & 308.12 & 980.88 \\
Subsidiary 8 & 227.59 & 206.90 & 203.11 & 637.60 \\
Parent company & 8402.57 & 7969.27 & 7545.32 & 15917.16 \\
\hline
\end{tabular}

Table 4. The terminal value estimated to be gained by each subsidiary of the group during 2011 to 2013.

\begin{tabular}{lc}
\hline CGU & Terminal Value \\
\hline Subsidiary 1 & 44446.93 \\
Subsidiary 2 & 22725.50 \\
Subsidiary 3 & 13192.81 \\
Subsidiary 4 & 10359.18 \\
Subsidiary 5 & 7193.35 \\
Subsidiary 6 & 9158.06 \\
Subsidiary 7 & 6136.75 \\
Subsidiary 8 & 3991.25 \\
Parent company & 107214.56 \\
\hline
\end{tabular}

Table 5. Residual value estimated to be gained by each subsidiary of the group during 2011 to 2013.

\begin{tabular}{lc}
\hline CGU & Residual value \\
\hline Subsidiary 1 & 51557.44 \\
Subsidiary 2 & 26360.58 \\
Subsidiary 3 & 15302.66 \\
Subsidiary 4 & 12015.65 \\
Subsidiary 5 & 8343.31 \\
Subsidiary 6 & 10622.35 \\
Subsidiary 7 & 71176.63 \\
Subsidiary 8 & 4628.85 \\
Parent company & 123131.72 \\
\hline
\end{tabular}

consolidation and to the favourable exchange rates in the case of subsidiaries from outside of Europe; the negative difference, that is, the impairment of goodwill, is determined by the impairment test and by excluding the assets from the consolidated statement.

The impairment test carried out at the end of the 2010 accounting period has confirmed that the recoverable value of CGU is higher than the carrying book value, except for the subsidiaries that have recorded negative goodwill.

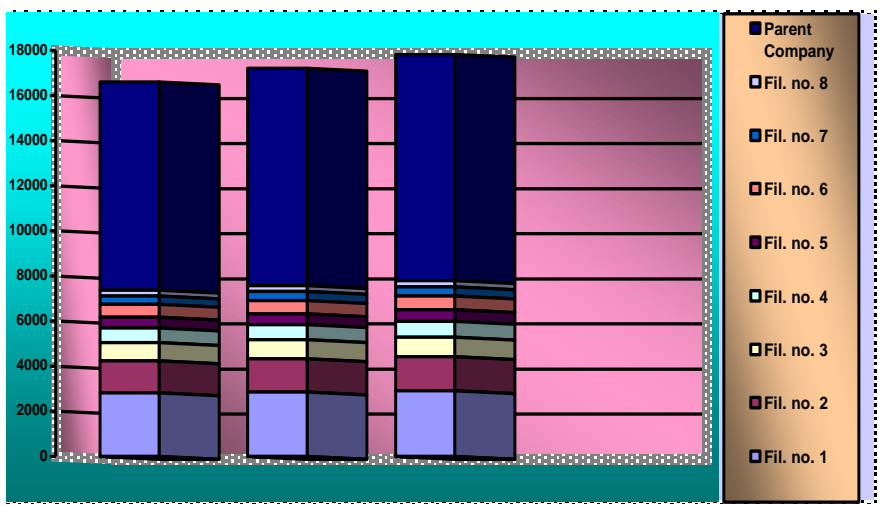

Graph 1. Evolution of CGU value estimated by the Beta S.A group for the period 2011 to 2013.

\section{CONCLUSIONS}

As could be observed throughout the present analysis, the value of goodwill can have a significant impact on the value of the other assets; after the mandatory observance of the IAS/IFRS accounting standards in the preparation of the annual or quarterly financial statements of the companies that are quoted on the stock market in the EU, starting with January 1st 2005, the amortisation of goodwill is no longer possible and its value must undergo yearly or even more frequent valuations, by means of the impairment tests as provided by the IAS 36 - Impairment assets standard. This provision has brought about significant changes that affected the value of the assets held by all the companies in this situation, with serious effects on the quality, reliability and integrity of the disclosed economic and financial information.

The analysis conducted in the second half of the paper has revealed that goodwill can acquire very high values upon acquisition by other entities, or it can be severely reduced after the exclusion of certain assets from the consolidated statement and often give rise to confusion and distrust among all categories of stakeholders. 


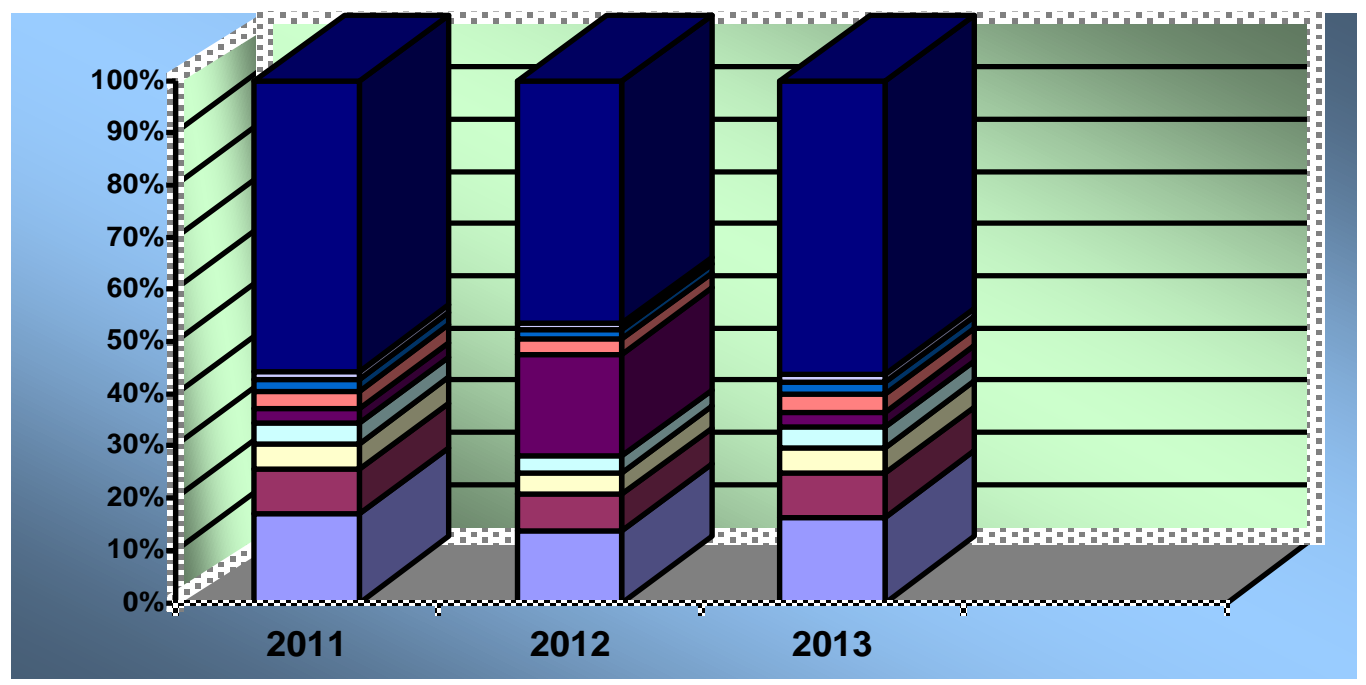

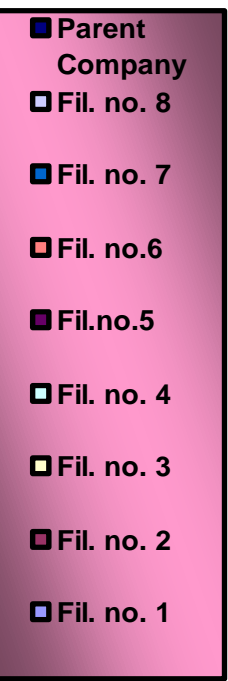

Graph 2. The evolution of the value in use of the future CGU estimated to be gained by each subsidiary during 2011 to 2013.

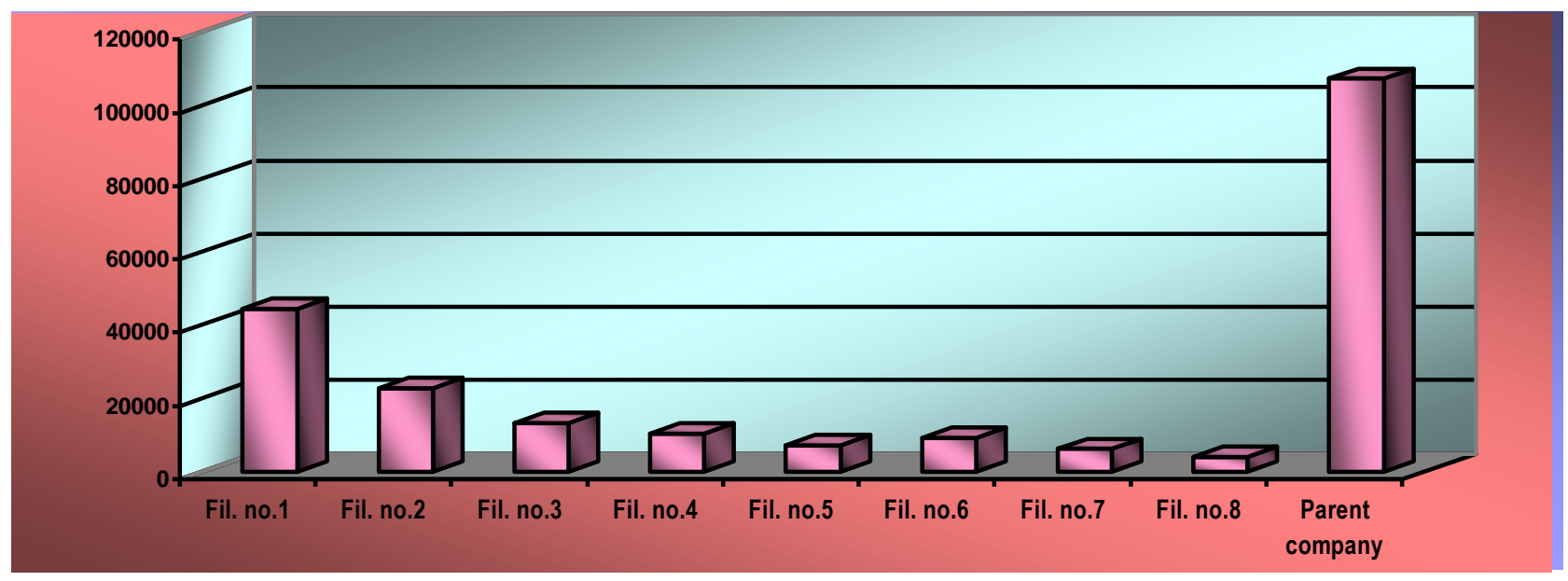

Graph 3. Evolution of the terminal value of CGU on a group level at the end of the frame of reference 2011 to 2013.

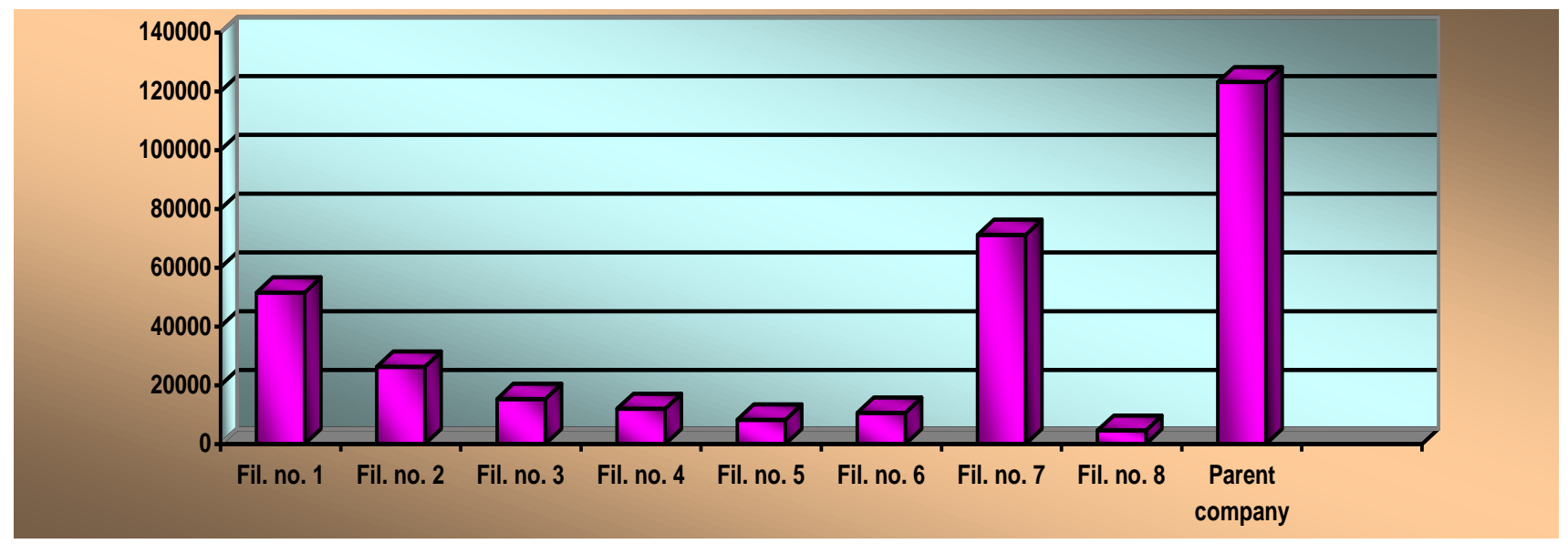

Graph 4. Evolution of the residual value of CGU on a group level, at the end of the frame of reference 2011 to 2013. 


\section{ACKNOWLEDGEMENT}

This work was supported by the project "Post-Doctoral Studies in Economics: training program for elite researchers - SPODE" co-funded from the European Social Fund through the Development of Human Resources Operational Programme 2007 to 2013, contract no. POSDRU/89/1.5/S/61755.

\section{REFERENCES}

Besta F (1922). La Ragioneria, Vallardi, 2-a ED, Milano.

Bianchi M (1996). Interpretazione del concetto avviamneto. Analizi dei principali orientamenti della dottrina italiana, Giuffre, Milano.

Blasi L (2010). La valutazione dei beni immateriali. Istituto Nazionale per il Commercio Estero, no. 10, Available at www.newsletter.fotonica.com.

Boisiso O (1964). II valore di avviameneto, Pirola, Milano.

Burciu A, Bostan I, Buta S (2010). Economia firmei, TipoMoldova Ed., lasi.

Charles E, Stanley J, Clark J (2004). Big Bath Earnings Management: The Case of Goodwill Impairment Under SFAS No. 142, Available a http://www.journals.cluteonline.com/index.php/JABR/article/view/220 6/2183. J. Appl. Bus. Res. 20:2.

Chirichiagno S, Segre V (2011). Formule specifiche per la determinazione dell'avviamento nei transferimenti d'azienda. Available at http://www.cms-aacs.com/Formule-specifiche-per-ladeterminazione-dellavviamento-nei-trasferimenti-dazienda-01-022011. Rivista delle operazione Staordinari, p. 9-16.

De Minico L, Amodeo D (1942). Saggi di economia aziendali. Giuffre, Milano.

De Muri P (2005). La valutazione delle aziende", Incontri di formazione 2004/2005. Available a www.adactastudio.com.

Ernest and Young (2005). IFRS 3-IAS 36, Nozioni di base e criticita. Milano.

Available

www.associazioneir.it/v1/en/publications/ppt/fcp.ppt.

Ernest and Young (2007). La valutazione delle imobilizzazioni immateriali. Intelectual Propriety. Imola. Available at http://www.innovami.it/doc/ipr/070509Colombo_Valutazione_IP.pdf.

Fabris G, Minestrone L (2004). Vallori della marca. Franco Angeli, Milano.

Feleaga L, Feleaga N (2006). Controverse privind politicile de evaluare, depreciere si contabilizare a fondului comercial. Available a http://www.ectap.ro/controverse-privind-politicile-de-evaluaredeprecieresi-contabilizare-a-fondului-comercial-de-niculae-feleagaliliana-feleaga/a111/. Economie Teoretica si Aplicata 6:501.
Guatri L, Bini M (2005). Nuovo trattato sulla valutazione delle aziende. Egea, Milano.

Henning L, Lewis LS, Barry L, Shaw HW (2005). Valuation of the Components of Purchased Goodwill. USA. J. Account. Res. 38:2.

Itami H (1987). Mobilizing Invisible Assets. Harvard Press, Massachusetts.

IASB: IAS 36-Impairment of Asset, awailable a www.iasb.com.

IASB: IFRS 3-Business Combination, awailable a www.iasb.com

Istrate C (2010). Contabilitatea nu-i doar pentru contabili!. Universul Juridic Bucuresti.

Lev B (2001). Intangibles: Management, Measurement and Reporting. Brookings Institution Press, Washington DC.

Mates D, David D (2010). Contabilitatea financiară în conformitate cu Directiva a IV-a şi a VII-a a UE. Editura Gutenberg, Arad.

Mironiuc M (2009). The scientific background of financial and accounting management (Fundamentele ştiinţifice ale gestiunii financiar-contabile). Al. I. Cuza University Ed. Iaşi.

Onida P (1974). II bilancio dell'impresa. Le sue differenziazione e la sua interpretazione. Giuffre, Milano.

Pettinicchio O (2004). Nuovo IFRS 3 e trattamento contabile dell'avviamento nella riforma del diritto societario. Libro Bianco. Available a www.iasitalia.it.

Renoldi A (1992). La valutazione dei beni immateriali. Metodi e soluzioni ,Egea, Milano.

Taliento M (2001). Measuring Goodwill Rationales for a Possible Convergence betwen the Excess Profits Estimate and the Rsidual Value Approach. J. Am. Acad. Bus. Cambridge p. 10.

Tiron TA (2005). Combinări de întreprinderi - fuziuni şi achiziţii, Editura Accent, Cluj Napoca.

Visconti RM (2009). La valutazione economica dell' avviamento. II diritto industriale, 5: 470-481. Available at http://www.odceccatanzaro.it/attachments/099 Valutazione\%20avvia mento.pdf.

Yang JM (1927). Goodwill and other intangibles: their significance and treatment in accounts. The Ronald Press Company, New York p. 29.

Yuan D, Hervé S, Jacques R (2007). Towards an understanding of the phases of goodwill accounting in four Western capitalist countries: From stakeholder model to shareholder. HEC Paris in its series Les Cahiers de Recherche with number 872. Available a http://ideas.repec.org/p/ebg/heccah/0872.html\#provider.

Zanda G (1974). La grande impresa. Caratteristiche sttruturali e di compartamento". Giuffre, Milano.

Zanda G, Onesti T (2005). La valutazione delle aziende. Giappicheli, Va Ed. Torino.

Zappa G (1950). II reditto d'impresa. Giuffre, Milano. 